\title{
Information Literacy Evaluation Index of Police College Students Based on AHP
}

\author{
Liang $\mathrm{HU}^{1,2}$, Guang-wei Zhao ${ }^{1}$ \\ ${ }^{1}$ JiangXi Police College, NanChang City, Jiangxi Province, P.R.China \\ ${ }^{2}$ Collaborative Innovation Center for Economics crime investigation and prevention technology, Jiangxi Province, P.R.China \\ huliang thu@163.com
}

\begin{abstract}
Information literacy is a kind of ability that university students use information technology to acquire knowledge, so the cultivation of information literacy in police colleges is particularly important because of its particularity. In view of the lack of information literacy evaluation criteria for Public Security College students, this paper takes public security college students as the research object, designs a questionnaire survey to collect data, constructs an information literacy evaluation index system, and calculates the weight of indicators by using analytic hierarchy process. The results show that the index system can effectively evaluate the information literacy of police college students.
\end{abstract}

Keywords-Public Security Colleges; University students; Information literacy; Evaluation index

\section{INTRODUCTION}

Information literacy was first proposed by Paul Zur Kowski in 1974, and it is summarized as "the technology and skill of using a large number of information tools and main information sources to get answers to questions". College student information literacy refers to their ability to search, evaluate, utilize and create information to solve problems in the process of learning [1-2]. As the reserve force of police officers in our country, police college students will not only directly participate in the information construction of public security in the future, but also serve the public on behalf of public power. Their basic qualities represent the image of public security organs in the public mind. Therefore, how to strengthen the training of student information literacy in public security colleges and strengthen their comprehensive quality and learning ability has become a practical problem to be explored and solved urgently [3-4].

\section{SEARCH SIGNIFICANCE}

The establishment of evaluation index system of information literacy ability is conducive to correctly guiding the cultivation process of student information literacy ability, clarifying the different roles of various indicators in the cultivation process, and promoting students' all-round development.

\section{A. Arousing university student attention to information literacy education}

First of all, colleges and universities are the guiding force of information literacy education for university students. The introduction of information literacy standards for college students has a clear and clear guiding role for individual college students. It also has certain guiding significance for the establishment and improvement of the corresponding curriculum. Secondly, the actual situation of university students' information literacy needs to be optimized. Mainly in the face of massive information, college students tend to lose themselves, or form excessive dependence on information. All these need to be solved under a complete guidance system. Thirdly, college students have confidence in information literacy courses. The current information literacy curriculum has a utilitarian tendency the same as taking college students as an educational goal. This deviates from the essence of information literacy education, and makes college students misunderstand or even deviate from information literacy education. To cultivate information literacy, we should cultivate the awareness of information capture and analysis. It is far from enough to educate college students with information literacy only through grading training. Finally, we need to understand the needs of College Students' information literacy. Through the evaluation, it can well reflect what deficiencies and needs students still have in information literacy ability. In view of these shortcomings, colleges and universities can put forward corresponding countermeasures [5-6].

\section{B. Providing feedback for the correct teaching of teachers in information courses}

It is not enough for university information curriculum education to take computer basic education as its content. Information literacy ability education covers a wide range, which puts forward higher requirements for professional teachers. The establishment of information literacy competence evaluation criteria is conducive to teachers in this field to clarify their own tasks, improve teaching methods, and achieve the goal of information literacy cultivation. First of all, the educational process has continuity and is the result of interaction between subject and object. Teachers' teaching and students' learning is a contradiction between them. Teachers get teaching results from student learning, improve teaching methods, and students learn knowledge and skills from teachers' courses. Secondly, the educational process is 
repeatable. The realization of educational goals lies in the repeated learning cycle of students. This cycle will be repeated on the freshmen in the next few years, or if the teacher's same course involves several groups, it will be repeated on several groups of students at the same time. Therefore, in the repeated cycle, the establishment of evaluation index system provides timely information feedback for teacher.

\section{CONSTRUCTION OF INFORMATION LITERACY EVALUATION INDEX SYSTEM}

\section{A. Guiding principles}

Directionality: The evaluation index system should embody the value orientation of information literacy education for students in public security colleges and universities. It can play a guiding role in the formation and development of individuals and the reform of information literacy education [7].
Feasibility: The design of the evaluation index system is practical, easy to obtain and describe, and the evaluation method can effectively statistic the evaluation information and is simple and feasible.

Scientificity: The evaluation index system includes quantitative and qualitative evaluation indexes, which can accurately and effectively measure the information retrieval and utilization ability of students [8].

\section{B. Evaluation latitude}

Based on the "Information Literacy Competence Standard of American Colleges and Universities", this paper establishes an evaluation index system for information literacy of Public Security College students, and determines the weight of indicators at all levels by using AHP method.

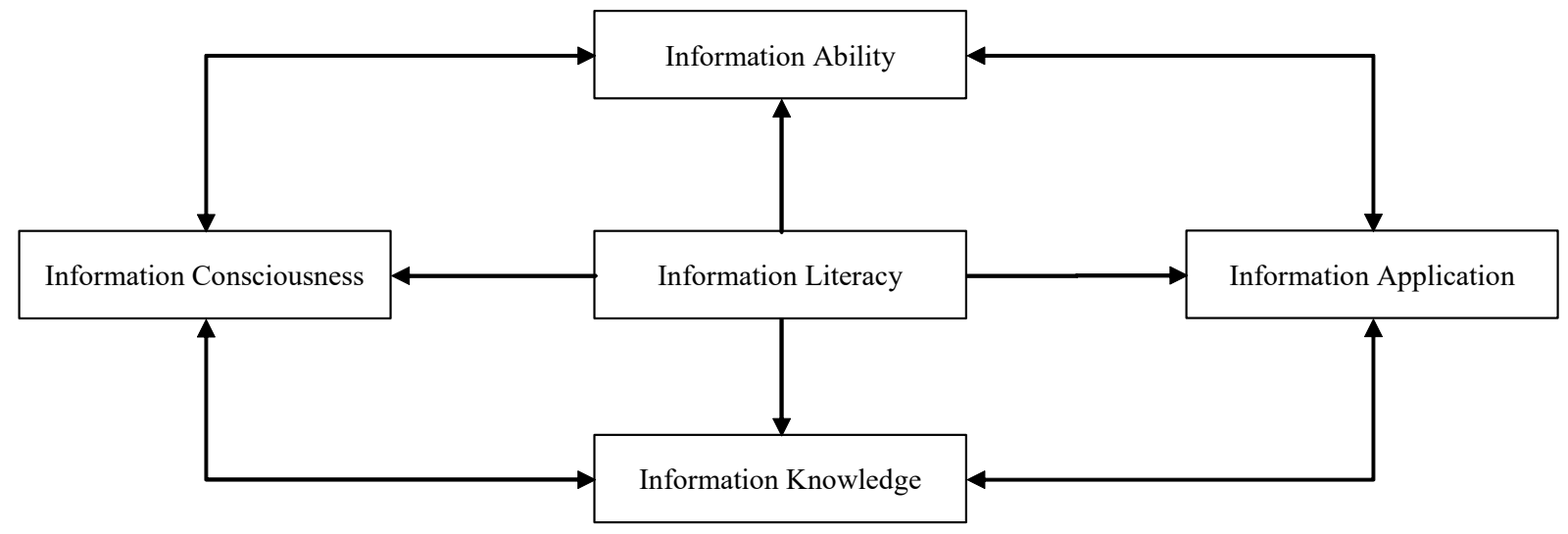

Fig. 1 Latitude of information literacy evaluation

Information Consciousness: it refers to the psychological qualities of the police, such as feeling, perception, emotion, will, etc.

Information Ability: it refers to the ability of obtaining, analyzing, processing and applying information that the police should possess in police work.

Information Knowledge: it refers to the police's understanding of the basic knowledge of information, and their mastery of information sources, information retrieval tools and retrieval methods. Information knowledge is an important part of information quality. The degree of mastery of information knowledge is related to the strength of police information awareness and information skills.
Information Application: it refers to the process of integrating information and making use of information to achieve the purpose of information.

\section{Information literacy evaluation index model}

The formulation of evaluation indicators must be based on a certain actual situation, taking into account different objects and different standards. Referring to the information literacy standards of domestic college students, this paper puts forward an evaluation index model of information literacy of public security college students on the basis of literature and questionnaire survey. 


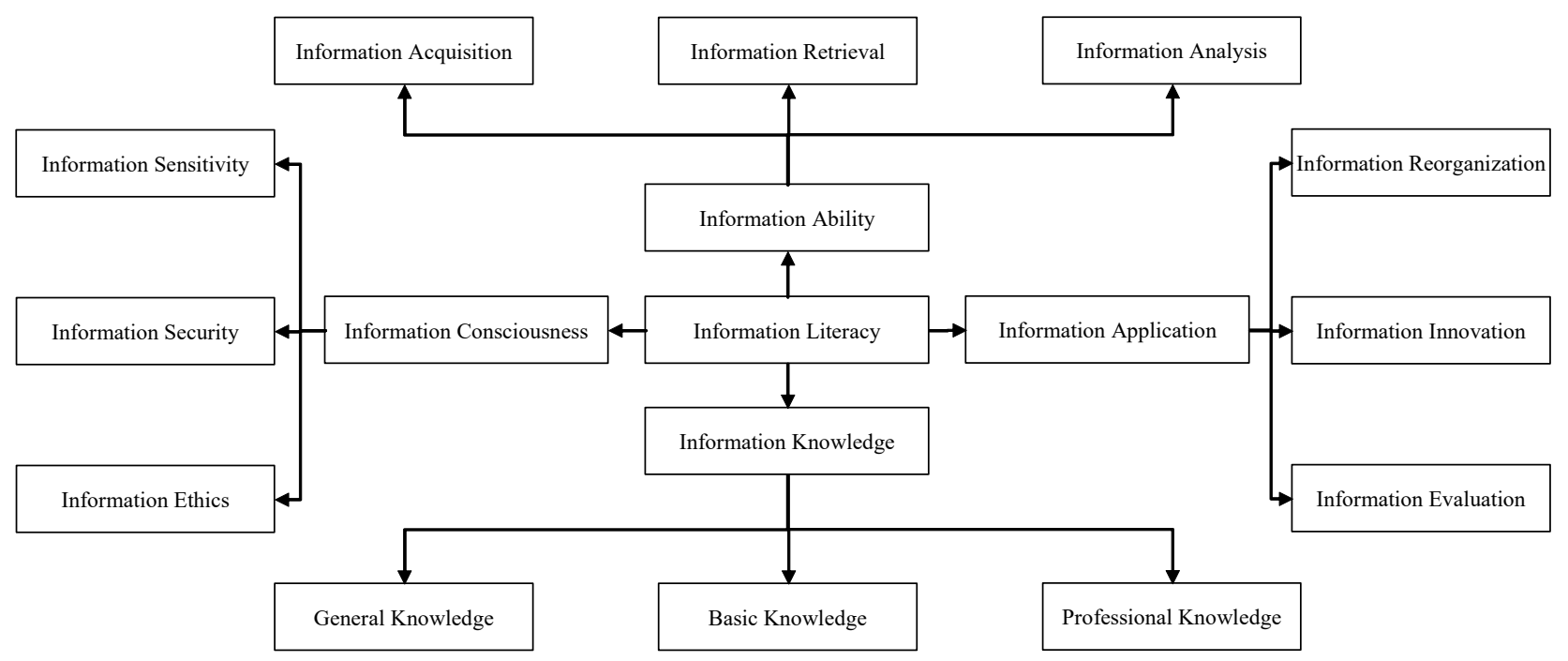

Fig. 2 Information literacy evaluation index model

\section{Constructing judgment matrix}

Analytic hierarchy process (AHP) was put forward by T.L.Saaty, Professor of University of Pittsburgh in 1973. This paper designs a scoring table based on AHP, compares the importance of each index at the same level in two ways, and gives the score of importance degree in the scoring table. The element AIJ in the judgment matrix $\mathrm{P}$ refers to the importance of the I row index relative to the $\mathrm{j}$ column index. Score 1 indicates that the index of row I is as important as that of column $\mathrm{j}$, score 3 indicates that the index of row I is slightly more important than that of column $\mathrm{j}$, score 5 indicates that the index of row I is more important than that of column $\mathrm{j}$, score 7 indicates that the index of row I is more important than that of column $\mathrm{j}$, and score 9 indicates that the index of row I is more important than that of column J.

TABLE I. JUDGMENT MATRIX

\begin{tabular}{|c|l|}
\hline Value & \multicolumn{1}{|c|}{ Description } \\
\hline $\mathbf{1}$ & Two indicators compared to the same degree of importance \\
\hline $\mathbf{3}$ & $\begin{array}{l}\text { Two indicators compared to an indicator is a little more important } \\
\text { than another }\end{array}$ \\
\hline $\mathbf{5}$ & $\begin{array}{l}\text { Two indicators compared to an indicator is significantly more } \\
\text { important than another }\end{array}$ \\
\hline $\mathbf{7}$ & $\begin{array}{l}\text { Two indicators compared to an indicator is very important than } \\
\text { another }\end{array}$ \\
\hline $\mathbf{9}$ & $\begin{array}{l}\text { Two indicators, an indicator than the other indicators of extreme } \\
\text { importance }\end{array}$ \\
\hline
\end{tabular}

When the order of the judgment matrix $\mathrm{P}$ is greater than 2 and the consistency ratio $\mathrm{CR}$ is less than 0.10 that it is considered that the judgment matrix is consistency, otherwise the judgment matrix needs to be adjusted.

$$
C R=\frac{C I}{R I}
$$

Among them, RI is the average random consistency index of judgment matrix. In this paper, the average random consistency index table of the 1-10 order matrix is given.

TABLE II. MEAN RANDOM CONSISTENCY INDEX TABLE

\begin{tabular}{|c|c|c|c|c|c|c|c|c|c|c|}
\hline $\begin{array}{c}\text { Matrix } \\
\text { order }\end{array}$ & 1 & 2 & 3 & 4 & 5 & 6 & 7 & 8 & 9 & 10 \\
\hline RI & 0.00 & 0.00 & 0.58 & 0.90 & 1.12 & 1.24 & 1.32 & 1.41 & 1.45 & 1.49 \\
\hline
\end{tabular}

\section{E. Compute index weight}

Information quality model has two levels of indicators, the first level indicators for information awareness, information knowledge, information skills, information applications, the second level indicators for information sensitivity, information security, information ethics, general knowledge, basic knowledge, professional knowledge, information acquisition, information retrieval, information retrieval information analysis, information reorganization, information innovation and information evaluation. 
TABLE III. INDEX WEIGHT OF INFORMATION LITERACY

\begin{tabular}{|c|c|c|c|c|}
\hline & First Level Index & Weight & Second Level Index & Weight \\
\hline \multirow{12}{*}{ Information Quality Index } & \multirow{3}{*}{ Information Consciousness } & \multirow{3}{*}{0.302} & Information Sensitivity & 0.525 \\
\hline & & & Information Security & 0.174 \\
\hline & & & Information Ethics & 0.301 \\
\hline & \multirow{3}{*}{ Information Knowledge } & \multirow{3}{*}{0.288} & General Knowledge & 0.393 \\
\hline & & & Basic Knowledge & 0.129 \\
\hline & & & Professional Knowledge & 0.478 \\
\hline & \multirow{3}{*}{ Information Ability } & \multirow{3}{*}{0.253} & Information Acquisition & 0.433 \\
\hline & & & Information Retrieval & 0.373 \\
\hline & & & Information Analysis & 0.194 \\
\hline & \multirow{3}{*}{ Information Application } & \multirow{3}{*}{0.157} & Information Reorganization & 0.387 \\
\hline & & & Information Innovation & 0.381 \\
\hline & & & Information Evaluation & 0.232 \\
\hline
\end{tabular}

\section{DISCUSSION AND FUTURE WORK}

Information literacy is an indispensable ability for college students to adapt to the information society. It helps college students to process and use all kinds of information when they need to obtain information. At the same time, we should improve the supervision mechanism of campus information, strengthen the moral safety education of campus network, establish the correct legal concept, improve the information morality of College students, and create a safe campus network information environment at the same time.

\section{ACKNOWLEDGMENT}

This author's work is supported by JiangXi Science and Technology Research Project of Education Department(GJJ151193), JiangXi University Party Building Project (16DJQN065), JiangXi Police College Scientific Research Project(2016JGZB008) and JangXi Science Education Planning Project(17YB244).

This author's work also is supported by the Opening Project of Collaborative Innovation Center for Economics crime investigation and prevention technology, Jiangxi Province.

\section{REFERENCES}

[1] Yu Ling. Constructing an evaluation index system for university students' information literacy [J]. Adult Education In China, 2013 (21): 89-91. (In Chinese)

[2] Chen Xiaohong, Gao Fan. Research progress and Prospect of information literacy education at home and abroad in recent five years [J]. Library and Information Work, 2018, 62 (10): 136-142. (In Chinese)

[3] Shi Yinghui, Peng Changling, Wu Hao, Yang Hao. Study on the evaluation index system of information literacy for primary and secondary school students [J]. China Audiovisual Education, 2018 (08): 73-77. (In Chinese)

[4] Jiang Yuanyuan, Zhang Xiaojuan. A comparative study of information literacy index system and curriculum design between Chinese and American universities [J]. Library and information knowledge, 2010 (04): 58-64. (In Chinese)

[5] Luo Yi, Wei Zhichun. Information Literacy Improvement and Management Support for College Students: An Empirical Analysis Based on Structural Equation Model [J]. Modern Distance Education, 2018 (04): 36-43. (In Chinese)

[6] Zhao Li, investigation and Study on the information quality of Police Academies in public security colleges in the new era[D]. Dalian: Liaoning Normal University, 2006. (In Chinese)

[7] Li Yaojun. The information literacy of Chinese and American college students standard [J]. Journal of University Library, 2011, (1): 69-71. (In Chinese)

[8] Zhou Meifang. A comparative study on the evaluation criteria of information literacy at home and abroad $[\mathrm{J}]$. Journal of Library Science, 2013, (12): 15-18. (In Chinese) 